\title{
Venom-Induced Immunosuppression: An Overview of Hemocyte-Mediated Responses
}

\author{
Aylin Er, ${ }^{1}$ Olga Sak, ${ }^{1}$ Ekrem Ergin, ${ }^{2}$ Fevzi Uçkan, ${ }^{3}$ and David B. Rivers ${ }^{4}$ \\ ${ }^{1}$ Department of Biology, Faculty of Science and Literature, Balikesir University, Çağı̧ 10145, Turkey \\ ${ }^{2}$ School of Nursing, Gülhane Military Medical Academy, Ankara 06018, Turkey \\ ${ }^{3}$ Department of Biology, Faculty of Arts and Sciences, Kocaeli University, Izmit 41300, Turkey \\ ${ }^{4}$ Department of Biology, Loyola University Maryland, Baltimore, MD 21210, USA \\ Correspondence should be addressed to Aylin Er, asahin@balikesir.edu.tr
}

Received 1 March 2011; Accepted 22 May 2011

Academic Editor: Cui $\mathrm{Hu}$

Copyright @ 2011 Aylin Er et al. This is an open access article distributed under the Creative Commons Attribution License, which permits unrestricted use, distribution, and reproduction in any medium, provided the original work is properly cited.

Parasitic wasps are important natural enemies of several insect pests. They use a variety of methods to modulate their insect host for their progeny to develop. For example, the female wasp needs to avoid or suppress the host immune responses by introducing venom with or without virus like particles and/or polydnaviruses. The aim of this paper is to provide a synthesis of current knowledge regarding the immunosuppression of host immunity with venom in parasitoids that are devoid of symbiotic viruses. Special emphasis is given through disabling host hemocytes by venom of the endoparasitoid Pimpla turionellae (Hymenoptera: Ichneumonidae) with comparisons of venoms from other parasitoid species.

\section{Introduction}

Insects and other invertebrates defend their lives against foreign materials with their effective immune systems. The immune system is commonly divided into two major branches named innate (or natural) and adaptive (or acquired) immunity [1-3]. Although invertebrates have long been categorized as possessing only innate immunity, cumulative experimental data from invertebrates indicate that specificity and memory might exist in invertebrates [4]. However, functional evidence for this is still scarce [1]. The innate immune system of insects is divided into humoral and cellular defense responses $[2,5,6]$. Insects are known to possess an innate immune system capable of recognizing foreign (i.e., nonself) materials like parasitic wasp eggs and larvae. Innate immune responses include phagocytosis, nodulation, encapsulation, melanization, blood coagulation, and release of stress-responsive proteins and molecules $[1,2,5,6]$.

Once pathogens and/or invading organisms gain entry into the hemocoel of the host, they encounter innate defense mechanisms involving cellular and humoral responses [1]. Humoral defenses include the production of antimicrobial peptides (AMPs), reactive intermediates of oxygen or nitrogen, and the complex enzymatic cascades that regulate clotting or melanization of hemolymph [1,5-7]. In contrast, a cellular immune response that involves different types of hemocytes, which participate in pathogen clearance by phagocytosing microorganisms, trapping them in hemocyte aggregates nodules, or encapsulation of larger microorganisms and cytotoxic reactions is also triggered $[1-3,8]$. In fact, there is an overlap between humoral and cellular defense, since many humoral factors affect hemocyte function and hemocytes are an important source of many humoral molecules $[2,8]$.

Parasitic wasps have evolved a variety of strategies in avoiding host-cell-mediated immune responses [5, 6, 9-11]. Endoparasitoids have probably coevolved with their hosts and use host milieu both for nutrition and as regulatory signals [12]. To develop successfully in the hemocoel of their hosts, endoparasitoids suppress, modify, or regulate the host immune/defense system by maternally derived secretions by female wasp during oviposition $[5,9]$. These secretions include endosymbiotic viruses (e.g., polydnaviruses (PDVs), entomopoxvirus), virus-like particles (VLPs), ovarian fluids, teratocytes (derived from injected eggs), and venoms $[5,9$, 13-18]. 
Either alone or in combination with other maternal factors, parasitoid venom is known to have distinct functions, including inhibition or reduction of the hemocyte responses $[5,19]$. In most cases, venom enhances the effects of PDVs or calyx fluid rather than serving as separate immunological suppressants [16, 19-21]. However, in parasitoid species that are devoid of PDVs or other symbiotic viruses $[9,22-$ $26]$, venom would alone perturb host immune defenses and may complement or replace the functions of other maternal factors [24].

Examples of such parasitoids include Pimpla hypochondriaca Retzius (Hymenoptera: Ichneumonidae) [9, 22], Pteromalus puparum L. (Hymenoptera: Pteromalidae) [23, 24], Nasonia vitripennis Walker (Hymenoptera: Pteromalidae) [26, 27], Pimpla turionellae L. (Hymenoptera: Ichneumonidae) [25], Asobara citri (Hymenoptera: Braconidae) [28], Asobara tabida (Hymenoptera: Braconidae) [29], and Asobara japonica (Hymenoptera: Braconidae) [30].

The purpose of this paper is to summarize the general patterns of changes in host immunity after parasitism by parasitoid species. Emphasis is placed on studies in parasitoids that are devoid of PDVs. We will also discuss this subject with other parasitoid species that lack PDVs in their venoms.

\section{Mode of Action of Venom That Lacks PDVs}

In endoparasitoid and ectoparasitoid species that are devoid of PDVs and virus-like particles, venom appears to play a major role in suppression of host immunity $[9,23,25$, 26]. Venoms of parasitoids are notably known to disrupt host physiology, biochemistry, and development by evoking paralysis, through inhibition of host molting, and by disrupting calcium homeostasis in specific host tissues in some cases [9, 22, 25, 31-39]. The composition of venom from Hymenoptera may vary within groups or even species [40-42]. Several studies have revealed the composition of parasitoid wasp venoms to be a complex cocktail of lowand high-molecular-weight compounds such as amines, peptides, proteins, enzymes, and glycoprotein [22, 39, 40, 43-61]. This complexity of venom enables parasitoids to avoid variations in the susceptibility of different hosts to a single component and to adapt for a wide range of hosts [60].

The physiological effects of wasp venoms vary depending on the host species and stage attacked [21, 35, 37, 62]. For example, idiobiont parasitoids possess venom that paralyzes or kills the host $[63,64]$, whereas koinobiont venoms cause an arrest or slow growth and development [22, 34, 37, 65, 66]. Moreover, qualitative and quantitative changes in venom content arise with changes in the physiological state of the wasp associated with age and source of food available for adult females [67].

\section{Alterations in Total and Differential Hemocyte Count}

In endoparasitic wasps not transmitting PDVs, venom has been shown to paralyze $[22,25]$, castrate the host [68], have an antibacterial effect [69], or affect the host immune system [10, 23, 70-72]. Inhibition of host immune responses is critical for endoparasitic species to ensure that eggs and larvae are not recognized and eliminated by the cellular arm of the immune defenses. Protection for wasp progeny generally is achieved through disabling host hemocytes [71].

Several authors have reported on the effects of parasitism on total and differential hemocyte counts in different insect hosts. Recently, studies have been conducted to examine the effects of parasitism and venom from $P$. turionellae on total and differential hemocyte numbers in two developmental stages of the host, Galleria mellonella (Lepidoptera: Pyralidae) [71]. Total hemocyte count indicated a considerable decline in the number of circulating hemocytes in G. mellonella pupae and larvae exposed to $P$. turionellae or any dose of wasp venom below the $\mathrm{LD}_{99}$ calculated for $G$. mellonella pupae and larvae [25] injected experimentally [71]. Also, significant variations in the number of differential hemocyte counts of G. mellonella occurred among parasitization and venom treatments in vivo [71]. Significant decreases in the percentage of granulocytes and increases in the percentage of plasmatocytes were observed at different time intervals at pupal and larval stages of G. mellonella [71]. In vitro assays with isolated $G$. mellonella hemocytes revealed that addition of an $\mathrm{LC}_{99}$ dose of venom $(0.001 \mathrm{VRE} / \mu \mathrm{L})$ induced some vacuole formation in both plasmatocytes and granular cells within $15 \mathrm{~min}$ of treatment [71]. However, the degree of vacuole formation was much more extensive in granular cells at later time points than for plasmatocytes, and granular cells seemed much more susceptible to venom as evidenced by cell death (Figure 1) [71].

The drop in cell numbers in venom-treated and parasitized hosts appeared to be due to hemocyte death. $P$. turionellae displays a broad host range [73] and can successfully oviposit in multiple life stages of the same hosts. Similarly, isolated venom has been shown to be toxic to a broad range of insects, including multiple developmental stages and cell types [25]. However, P. turionellae females select pupae over larvae for oviposition when given a choice and pupal hemocytes are more susceptible to parasitism and venom injection [71].

In several lepidopteran hosts, successful parasitization by parasitic wasps leads to a reduction in the total number of hemocytes in circulation $[74,75]$. Studies suggested that the number of hemocytes remaining in the hemolymph is an essential factor of the host immune defense reactions especially in encapsulation reactions around the parasitoid eggs. Decreases in hemocyte numbers and increases in hemocyte damage also occurred in experimentally envenomated insects $[70,76,77]$. In contrast, Zhang et al. [78] reported that parasitism by $P$. puparum resulted in a noticeable increase in total hemocyte numbers of its two hosts for a defined period. The same trend was also observed before by Eslin and Prevost [29] who reported an increase of hemocyte counts in larvae from six Drosophila melanogaster Fabr. (Diptera: Drosophilidae) subgroup species after parasitism by A. tabida.

A major part of our knowledge concerning the immune suppressive effects of parasitoids on their hosts comes from 


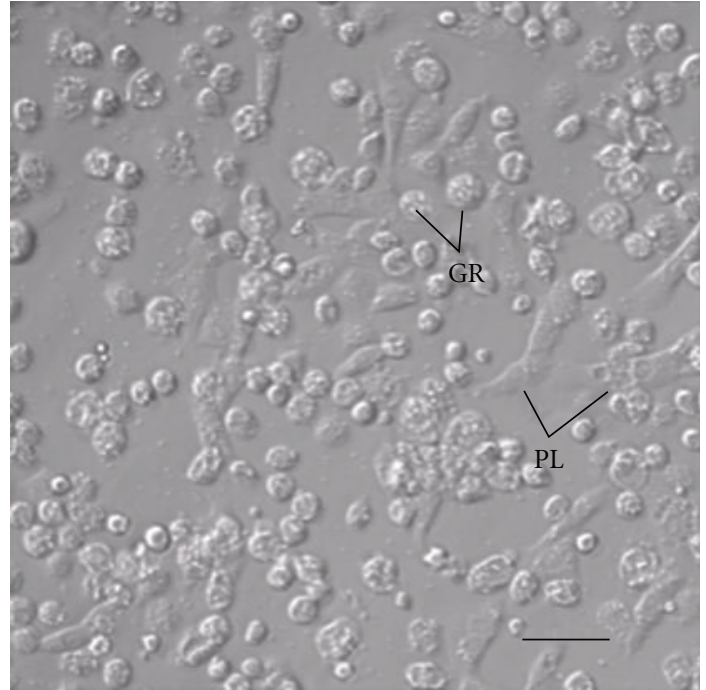

(a)

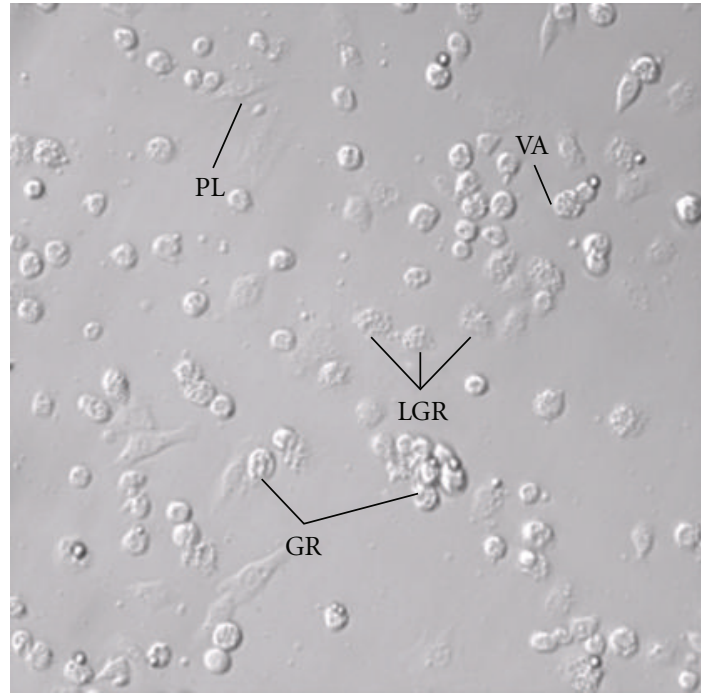

(b)

Figure 1: Phase-contrast micrographs of adhesive hemocytes from the last instars of G. mellonella cultured in vitro with isolated crude venom $(0.001 \mathrm{VRE} / \mu \mathrm{L})$ from $P$. turionellae. Hemocytes were incubated in vitro at $27^{\circ} \mathrm{C}$ for $1 \mathrm{~h}$ in TC-100 medium with $10 \%$ FBS before the addition of phosphate isolation buffer (a) or venom (b). Photomicrographs were taken at 45 min after treatment. GR: granular cells; PL: plasmatocytes; LGR: lysed granular cells; VA: vacuoles. Bar $=20 \mu \mathrm{m} *$ (Effects of parasitization and envenomation by the endoparasitic wasp Pimpla turionellae (Hymenoptera: Ichneumonidae) on hemocyte numbers, morphology and viability of its host Galleria mellonella (Lepidoptera:Pyralidae) [71]. Copyright [2010] Entomological Society of America).

PDVs or VLPs. In certain host parasitoid systems, action of venom components is necessary to enhance the effects of PDVs [79-81]. However, a limited number of studies suggest that venom from idiobiont endoparasitoids devoid of symbiotic viruses may alone affect total and differential hemocyte counts and hemocyte morphology as a part of perturbing host immune defenses (Table 1).

In certain host parasitoid systems, the reduction of hemocytes in circulation was caused by cell death [27, 63, 8285]. Apoptosis and/or oncosis appear to be necessary means to manipulate the host to ensure successful development of parasitoid larvae $[27,63,82-85]$. Recently, studies have been conducted to examine the ability of $P$. turionellae venom to induce cell death in the circulating hemocytes of the natural host G. mellonella at the larval and pupal stage [82]. The occurrence of apoptosis in venom-treated, parasitized, and untreated host larvae and pupae was detected using acridine orange/ethidium bromide double staining method (Figure 2) [82]. This method of detecting apoptosis is based on the loss of plasma membrane integrity as cells die [86]. Cells were identified as viable (green nucleus with red-orange cytoplasm with an intact membrane), early apoptotic (cell membrane still continuous but chromatin condensation and an irregular green nucleus are visible), late apoptotic (ethidium bromide penetrates through altered cell membrane and stains the nuclei orange, while fragmentation or condensation of chromatin is still observed), and necrotic (orange nucleus with intact structure) [86, 87]. Also venom-induced apoptosis was detected using an Annexin V-FITC and propidium iodide apoptosis detection kit [82].
The kit relies on cells undergoing early apoptosis translocating membrane phosphatidylserine (PS) to the cell surface [82].

Acridine orange/ethidium bromide double staining indicated that parasitism and experimental envenomation of $G$. mellonella by $P$. turionellae resulted in markedly different effects on the ratio of apoptotic hemocytes circulating in hemolymph depending on the host developmental stages [82]. The ratio of early and late apoptotic hemocytes increased more than $100 \%$ compared to untreated, null-, and PBS-injected controls for host pupae and larvae at higher doses of venom and after parasitization for pupae. Venom-induced apoptosis was also observed in vitro using hemocytes from the last instar larvae of $G$. mellonella double stained with an annexin-V-sensitive probe (conjugated to FITC) and propidium iodide (Figures 3 and 4) [82]. Staining of hemocytes with annexin V-FITC revealed green fluorescent "halos" along the plasma membranes of venomtreated cells within $15 \mathrm{~min}$ following exposure to venom. By $1 \mathrm{~h}$ after venom treatment, the majority of hemocytes displayed binding of this probe, indicative of early stage apoptosis. These same hemocytes also displayed a loss of plasma membrane integrity at the same time points as evidenced by accumulation of propidium iodide in nuclei [82].

The most common feature shared in the action of wasp secretions and viral products is the induction of cell death in selected tissues of the insect host [85]. Apoptosis and/or oncosis appear to be necessary means to manipulate the host to ensure successful development of parasitoid larvae 
TABle 1: Changes in total and differential hemocyte counts and hemocyte morphology induced by parasitism and venom from the parasitoids devoid of symbiotic viruses.

\begin{tabular}{|c|c|c|c|c|c|c|}
\hline \multirow{2}{*}{ Parasitoid } & \multirow{2}{*}{ Host } & \multirow{2}{*}{ Treatments } & \multicolumn{3}{|c|}{ Effects observed } & \multirow{2}{*}{ Ref. } \\
\hline & & & THC & DHC & Hemocyte Morph. & \\
\hline Pimpla turionellae & Galleria mellonella & $\begin{array}{l}\text { Parasitized } \\
\text { Venom }\end{array}$ & $\begin{array}{l}\text { Reduced } \\
\text { Reduced }\end{array}$ & $\begin{array}{l}\text { GR increased } \\
\text { PL reduced } \\
\text { GR increased } \\
\text { PL reduced }\end{array}$ & $\begin{array}{l}\text { (i) Vacuole formation } \\
\text { (ii) Membrane blebs }\end{array}$ & [71] \\
\hline Pimpla turionellae & $\begin{array}{l}\text { Cells derived from } \\
\text { Trichoplusia ni and } \\
\text { Aedes aegypti }\end{array}$ & Venom & & & $\begin{array}{l}\text { (i) Rounded } \\
\text { (ii) Plasma membranes } \\
\text { Swelled }\end{array}$ & {$[25]$} \\
\hline Nasonia vitripennis & $\begin{array}{l}\text { Cells derived from } \\
\text { Trichoplusia ni }\end{array}$ & Venom & & & $\begin{array}{l}\text { (i) Retract cytoplasmic } \\
\text { extensions } \\
\text { (ii) Rounded } \\
\text { (iii) Vacuole formation }\end{array}$ & [27] \\
\hline Nasonia vitripennis & Sarcophaga bullata & $\begin{array}{l}\text { Parasitized } \\
\text { Venom }\end{array}$ & $\begin{array}{l}\text { Reduced } \\
\text { Reduced }\end{array}$ & $\begin{array}{l}\text { PL reduced } \\
\text { PL reduced }\end{array}$ & $\begin{array}{l}\text { (i) Retract pseudopods } \\
\text { (ii) Rounded }\end{array}$ & [26] \\
\hline Asobara citri & Drosophila melanogaster & Parasitized & Reduced & $\begin{array}{l}\text { PL reduced } \\
\text { LM reduced }\end{array}$ & & [28] \\
\hline Asobara tabida & 6 Drosophila species & Parasitized & Increased & $\begin{array}{l}\text { PL increased } \\
\text { LM increased }\end{array}$ & & [29] \\
\hline \multirow[t]{2}{*}{ Asobarajaponica } & \multirow[t]{2}{*}{ Drosophila melanogaster } & $\begin{array}{l}\text { Parasitized } \\
\text { Venom }+ \\
\text { ovarian extract }\end{array}$ & $\begin{array}{l}\text { Reduced } \\
\text { Reduced }\end{array}$ & $\begin{array}{l}\text { PL reduced } \\
\text { PL reduced }\end{array}$ & No effect & {$[30]$} \\
\hline & & Ovarian extract & No changes & No changes & & \\
\hline $\begin{array}{l}\text { Pimpla } \\
\text { hypochondriaca }\end{array}$ & Lacanobia oleracea & Venom & Reduced & & $\begin{array}{l}\text { Extensive damage } \\
\text { disintegration }\end{array}$ & {$[10]$} \\
\hline $\begin{array}{l}\text { Pteromalus } \\
\text { puparum }\end{array}$ & Pieris rapae & $\begin{array}{l}\text { Parasitized } \\
\text { Venom }\end{array}$ & Increased & $\begin{array}{l}\text { PL reduced } \\
\text { GR increased }\end{array}$ & Rounded & [23] \\
\hline
\end{tabular}

$[63,76,89]$. Apoptosis, triggered by symbiotic viruses of parasitoid wasps has already been reported in previous studies. In Pseudoplusia includens Walker (Lepidoptera: Noctuidae) parasitized by Microplitis demolitor Wilkinson (Hymenoptera: Braconidae), infection with PDV induces host granulocytes to undergo apoptosis characterized by cell surface blebbing, fragmentation of DNA, and chromatin condensation, while plasmatocytes lose their capacity to adhere to foreign surfaces [90]. In Diachasmimorpha longicaudata Ashmead (Hymenoptera: Braconidae)/Anastrepha suspensa Loew (Diptera: Tephritidae) system, the entomopoxvirus of the parasitoid caused hemocyte apoptosis [91]. In Heliothis virescens Fabricius (Lepidoptera: Noctuidae) larvae parasitized by Toxoneuron nigriceps (Hymenoptera: Braconidae), total number of hemocytes decreased and the hemocytes showed different structural damages which suggested the occurrence of apoptosis and these hemocyte alterations selectively induced in granulocytes [92]. In Pseudaletia separata Walker (Lepidoptera: Noctuidae) parasitized by Cotesia kariyai (Hymenoptera: Braconidae), the hemocytes increased in number and PDVs induced apoptosis in the circulating hemocytes and hematopoietic organs [83]. Suzuki and Tanaka demonstrated that injection of Meteorus pulchricornis Wesmael (Hymenoptera: Braconidae) virus like particles into $P$. separata induced apoptosis in hemocytes, particularly granulocytes [93]. The authors suggested that induction of apoptosis could be triggered directly or indirectly by the viral gene products expressed in host cells [93]. It is speculated that the envelopes of VLPs seem to contain some ligands for penetration against receptors on the host cell surface and specificity between such ligands and receptors relates to susceptibility of host tissues to VLPs function [93]. Relatively, little is known about the mechanisms involved in hemocyte apoptosis induction triggered by endosymbiotic viruses or VLPs. Cytoplasmic bleb formation is frequently associated with plasma membranes of apoptotic cells and involves disruption of the cytoskeletal membrane interactions and is speculated to depend on the activation of $\mathrm{Ca}^{2+}$-dependent proteases $[85,94,95]$. Protease activation is dependent on an elevation of intracellular calcium and involvement of phospholipases $[85,96]$. Influx of $\mathrm{Ca}^{2+}$ through L-type calcium channels on the plasma membrane and mobilization of calcium from intracellular stores are primary effects of several animal viruses $[85,97]$.

Despite the lethal action of parasitic wasp venoms on their hosts, the molecular mechanisms caused by venom in suppressing host immunity and inducing death are partly unknown. In most cases, venom enhances the effects of PDVs or calyx fluid rather than serving as separate immunological suppressants [16, 19-21]. However, in parasitoid species that are devoid of PDVs or other symbiotic viruses venoms alone perturb host immune defenses. In the P. puparum/Pieris 


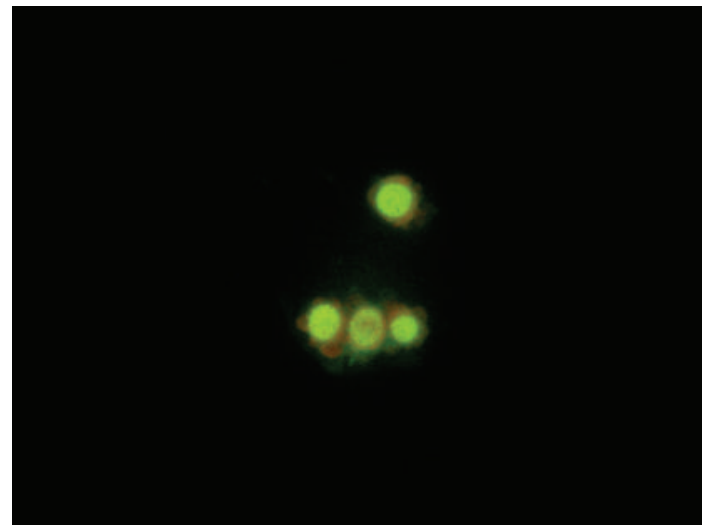

(a)

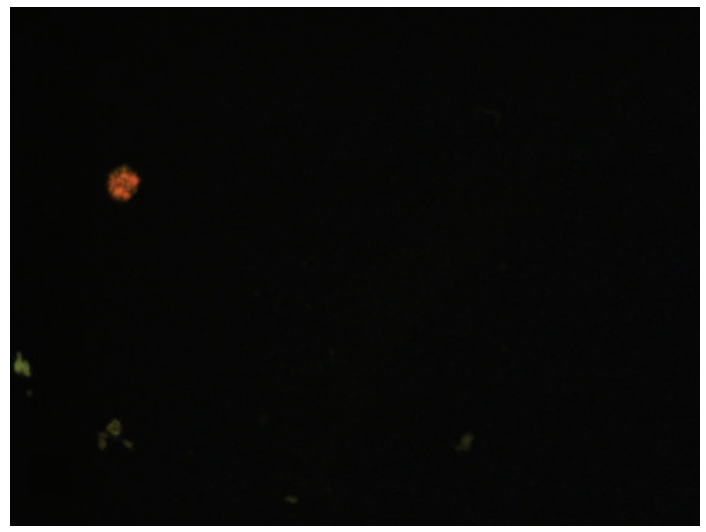

(c)

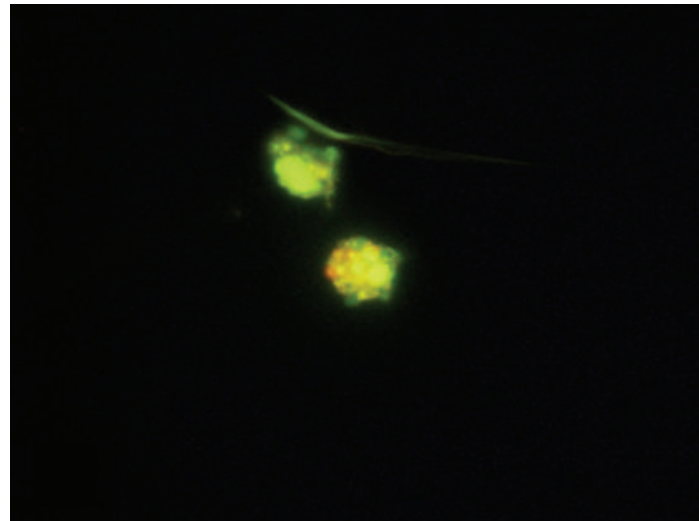

(b)

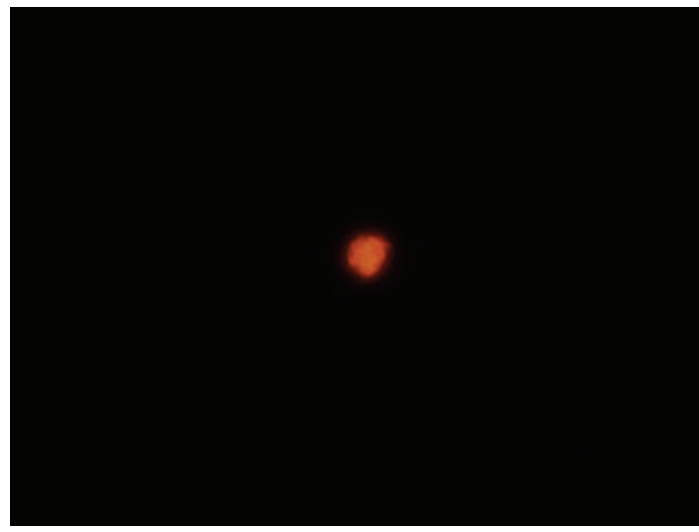

(d)

Figure 2: Acridine orange/ethidium bromide double staining of G. mellonella hemocytes with characteristic symptoms of apoptosis. (a) Normal hemocytes from untreated larvae, (b) early apoptosis, (c) late apoptosis, and (d) necrosis from parasitized larvae of G. mellonella. Scale bar $10 \mu \mathrm{m} *$ (Effects of parasitism and application of venom from the endoparasitoid Pimpla turionellae on hemocytes of the host Galleria mellonella [82]. Copyright [2010] Blackwell Verlag, GmbH).

rapae Linnaeus (Lepidoptera: Pieridae) system venom alone was shown to prevent spreading and encapsulation of hemocytes; however, staining of filamentous actin showed that the cytoskeleton of host hemocytes was not visibly affected by venom treatment [23]. Parasitization and high doses of venom from $P$. turionellae induced hemocyte apoptosis in the larval and pupal stage of the host G. mellonella [82]. Also observations revealed that when envenomation experiments are performed in media lacking a source of calcium, PI accumulates in the nucleus but annexin $\mathrm{V}$ does not bind to the hemocytes. These findings indicate that venom from $P$. turionellae induces apoptosis in hemocytes by a pathway dependent on extracellular calcium influx [82]. However information is lacking on how venom operates at the cellular level or interactions that occur between venom proteins and target hemocytes. Similarly, venom from $P$. hypochondriaca that lacks PDV and VLP kills the L. oleracea hemocytes by apoptosis in a dose-responsive manner [84]. Another study indicates that venom from $P$. hypochondriaca triggers apoptotic pathways leading to cell death in some cell types and active phenoloxidase in venom triggers apoptosis in cultured insect cells [98]. Venom from the ectoparasitic wasp
$N$. vitripennis causes the host hemocytes to die by an oncotic mechanism largely due to the induced cellular swelling [26]. However, further studies suggested that apoptotic and/or nonapoptotic programmed cell death is the primary mechanism of hemocyte death evoked by N. vitripennis venom [27]. The identification of calreticulin in both P. hypochondriaca and $N$. vitripennis makes it the candidate in venom to trigger apoptotic pathways [27, 99, 100]. Calreticulin is a $\mathrm{Ca}^{+2}$-binding protein that modulates calcium levels in both endoplasmic reticulum (ER) and mitochondria, and, hence, once in the intracellular environment, this protein could conceivably stimulate the venom-induced mobilization of intracellular calcium, which in turn would trigger numerous cellular changes including movement of the cytoskeletal filaments, swelling, and death by oncosis and apoptosis $[98,101]$. Also, laccase in venom from $N$. vitripennis has phenoloxidase activity, which could evoke disruption of plasma membrane integrity in susceptible cells, blebbing, rounding, and swelling, and it was suggested that, together with calreticulin, they could be involved in venom-mediated mobilization of intracellular calcium that ultimately leads to cell death $[61,102]$. The cytotoxic effects triggering apoptosis 


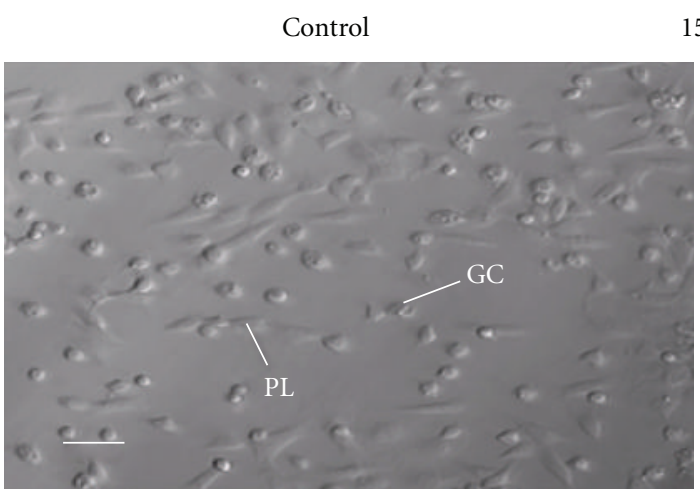

(a)

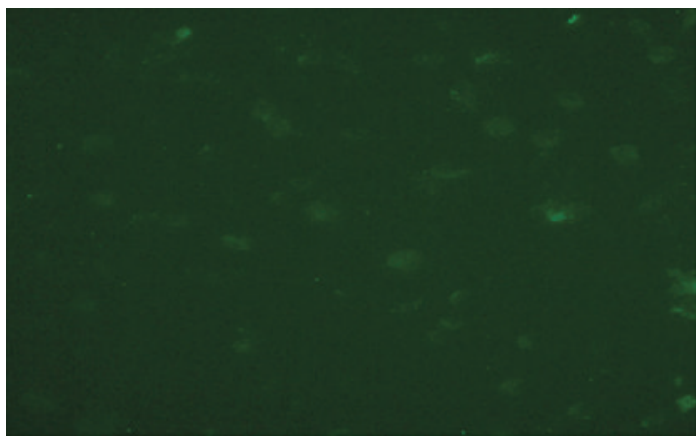

(b)

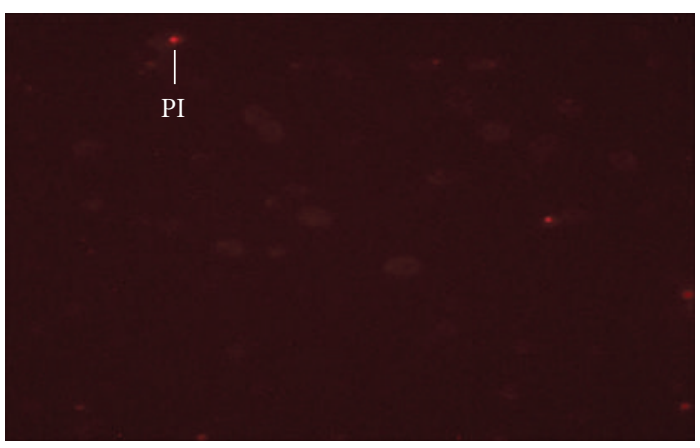

(c)
$15 \min$

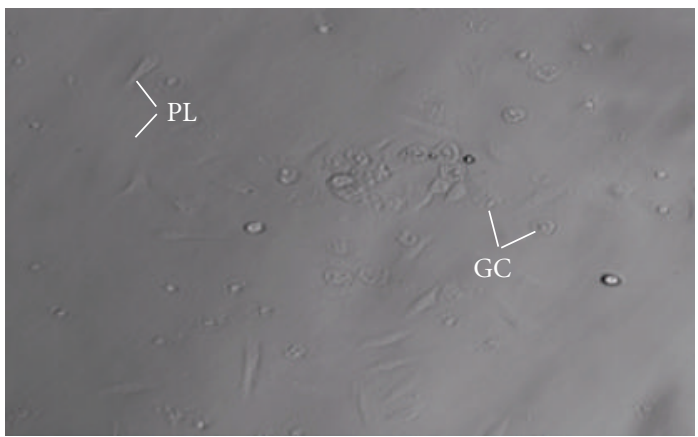

(d)

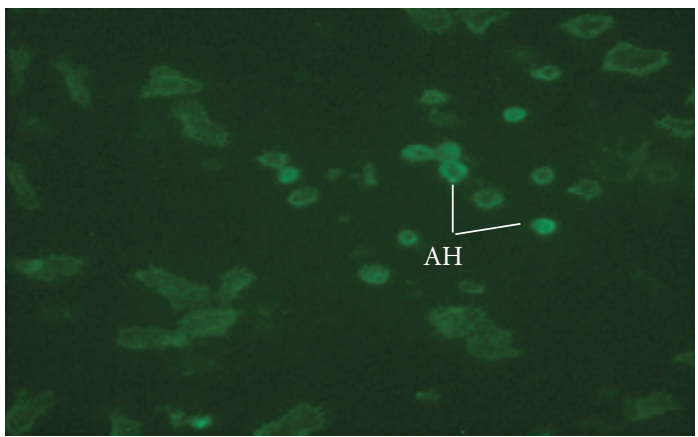

(e)

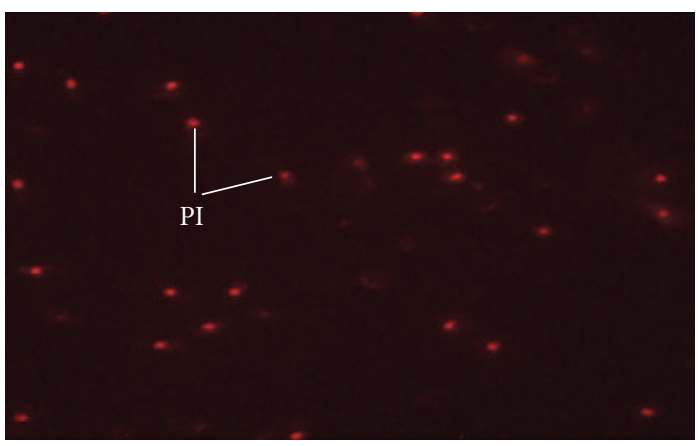

(f)

FIGURE 3: Fluorescence microscopy of hemocytes collected from G. mellonella incubated with crude venom from P. turionellae and double stained with an annexin-V-sensitive probe (conjugated to FITC) and propidium iodide. Qualitative labeling of annexin V in the plasma membrane (b and e) or cellular uptake of propidium iodide ( $\mathrm{c}$ and $\mathrm{f}$ ) was monitored $15 \mathrm{~min}$ after exposure to wasp venom. Cells exposed to PBS served as controls (a)-(c), and a 0.25 VRE dose of $P$. turionellae venom was used for toxicity assays (d)-(f). PL: plasmatocyte; GC: granular cell; AH: annexin halo; PI: propidium iodide. The bar corresponds to $18 \mu \mathrm{m}$. * (Effects of parasitism and application of venom from the endoparasitoid Pimpla turionellae on hemocytes of the host Galleria mellonella [82]. Copyright [2010] Blackwell Verlag, GmbH).

of parasitoid venoms that are not working with symbiotic viruses synergistically could also be attributed to the component metalloproteinases which were identified in wasp venom [53, 82, 100]. Previously apoptosis caused by snake venom metalloproteinases has been characterized in human endothelial cells $[103,104]$.

Another possible mechanism that is responsible for variations in the hemocyte numbers that is associated with parasitism in several host-parasitoid systems could be the suppression of cell cycle via parasitoid-derived secretions. It is known that the maintenance of circulating hemocytes is supplied by the mitosis of circulating hemocytes itself and from hematopoietic organs $[105,106]$. In G. mellonella, Bombyx mori Linnaeus (Lepidoptera: Bombycidae), and Euxoa declarata Walker (Lepidoptera: Noctuidae) mitosis in circulating hemocytes has been observed and it was confirmed that $1-8 \%$ of the population of circulating hemocytes is in the mitotic phase [105, 107-109]. Er et al. [82] recently showed that both parasitization and envenomation by $P$. turionellae venom resulted with a considerable decline in mitotic hemocytes in circulation of G. mellonella. Though there are few studies on the effect of endoparasitoid venom or parasitization on mitosis of host hemocytes, it was revealed that mitosis of circulating hemocytes halted after the injection of 


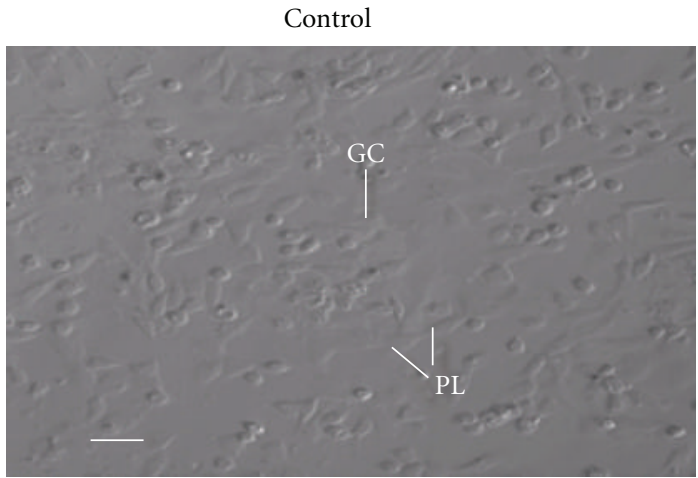

(a)

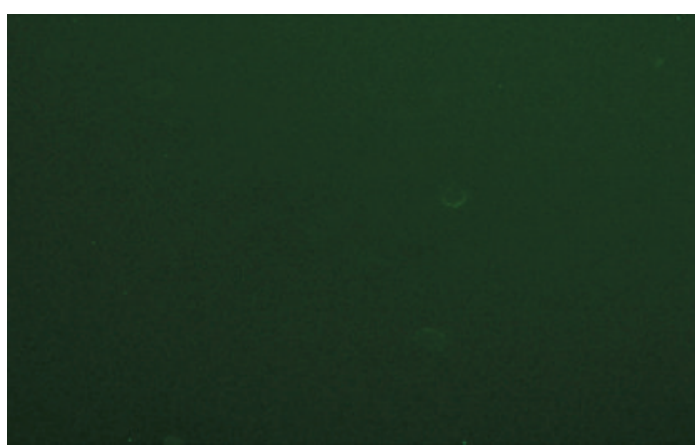

(b)

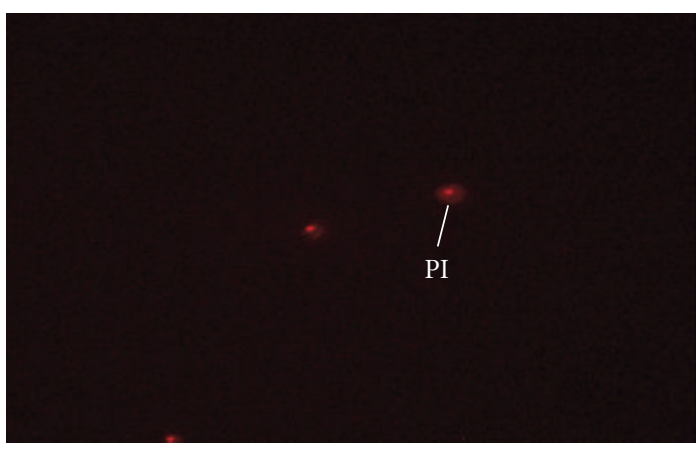

(c)
$1 \mathrm{~h}$

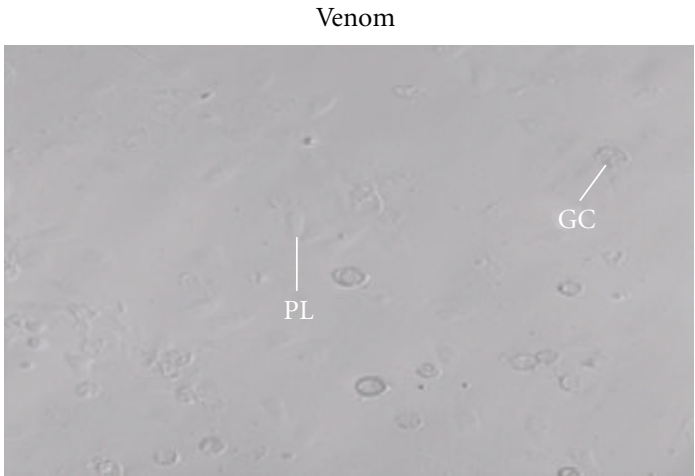

(d)

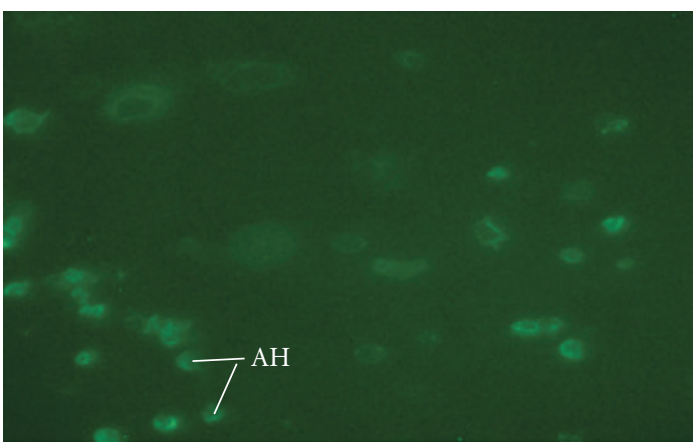

(e)

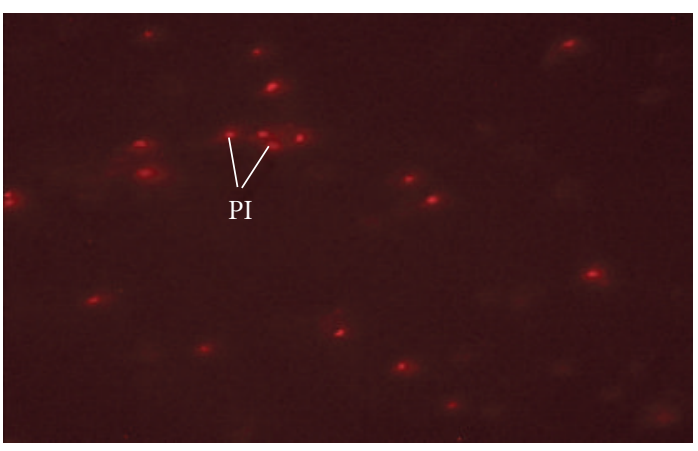

(f)

FIGURE 4: Fluorescence microscopy of hemocytes collected from G. mellonella incubated with crude venom from $P$. turionellae and double stained with an annexin-V-sensitive probe (conjugated to FITC) and propidium iodide. Qualitative labeling of annexin V in the plasma membrane (b and e) or cellular uptake of propidium iodide ( $\mathrm{c}$ and $\mathrm{f}$ ) was monitored $1 \mathrm{~h}$ after exposure to wasp venom. Cells exposed to PBS served as controls (a)-(c), and a 0.25 VRE dose of P. turionellae venom was used for toxicity assays (d)-(f). PL: plasmatocyte; GC: granular cell; AH: annexin halo; PI: propidium iodide. The bar corresponds to $15 \mu \mathrm{m}$. * (Effects of parasitism and application of venom from the endoparasitoid Pimpla turionellae on hemocytes of the host Galleria mellonella [82]. Copyright [2010] Blackwell Verlag, GmbH).

C. kariyai PDV plus venom into P. separata [83]. The authors demonstrated that the PDV plus venom caused the disappearance of the $4 \mathrm{C}$ and $8 \mathrm{C}$ ploidies, and PDV alone produced the humoral plasma factors that suppress the cell cycle [83]. Further investigation is needed concerning the mechanisms involved in cell cycle arrest as there are only a few studies on venom-induced changes in mitotic indices of the host.

\section{Encapsulation}

The major immune response towards internal parasites and other foreign entities that enter the insect's hemocoel is encapsulation $[72,90,110,111]$. The sequence of how different hemocyte types are engaged in encapsulation, including recognition, opsonization, recruitment of cells, and formation of a multilayer sheath, has also been described $[2,72,112,113]$. Encapsulation begins when host granulocytes attach to the surface of a foreign target. The attached granulocytes lyse or degranulate, releasing the contents of their granules over the foreign object. This is assumed to attract and allow the plasmatocytes to attach. Termination of capsule formation occurs when a subpopulation of granulocytes adheres in a monolayer around the periphery of the capsule $[5,14,72,114-116]$. The process is ultimately 


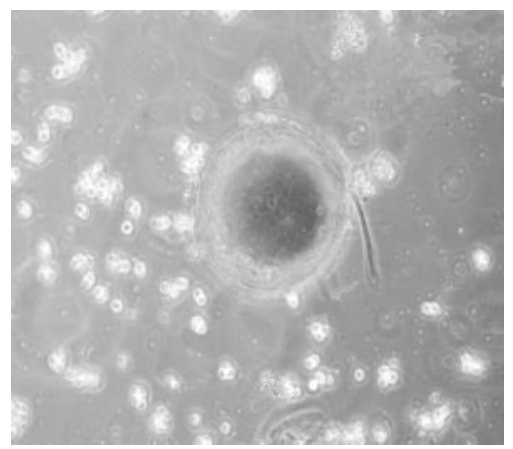

(a)

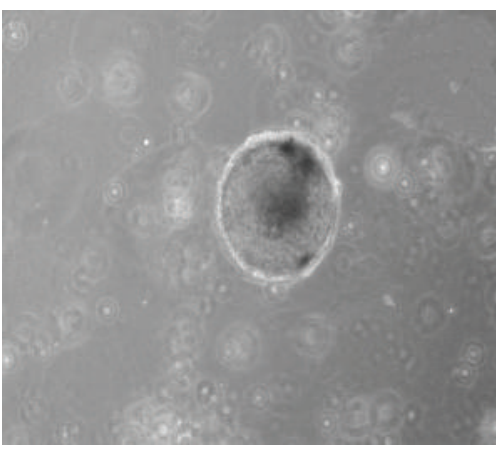

(b)

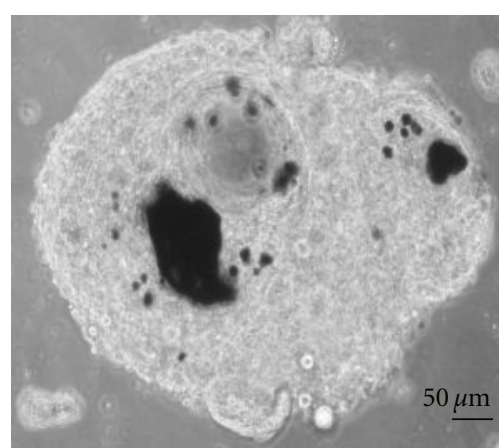

(c)

Figure 5: Encapsulation of Sephadex A-25 beads in G. mellonella larvae. (a) Negative (no or only a few beads attached to the bead), (b) weak (2-10 layers of hemocytes around the bead), AND (c) Strong (more than ten layers of hemocytes around the bead). *(Levels of encapsulation and melanization in Galleria mellonella (Lepidoptera: Pyralidae) parasitized and envenomated by Pimpla turionellae (Hymenoptera: Ichneumonidae) [72]. Copyright [2009] Blackwell Verlag, GmbH).

accompanied by blackening of the capsule because of melanization and finally the encapsulated organism almost always dies $[2,5]$. Several factors, including asphyxiation, the local production of cytotoxic quinones or semiquinones via the proPO activation cascade during melanization, free radicals, and antibacterial peptides have been suggested to function as killing agents $[1,2,110,117,118]$.

An important point of the encapsulation response in insects is associated with host-parasitoid relationships. Endoparasitoid species that lay their eggs into insect hosts must avoid encapsulation responses of the host hemocytes. According to Strand and Pech [115], the most direct way of preventing encapsulation is to destroy, deplete from circulation, or alter the behavior of the hemocytes that mediate encapsulation. Many parasitoids do this by introducing fluids at the time of oviposition that contain antihemocytic and/or immunosuppressive factors [119]. Some of these factors may be derived from PDVs or VLPs while others from venom produced by the adult female parasitoids. The role of PDVs, VLPs, and other ovarian fluids in suppression of host encapsulation ability in many parasitoid-host systems has been well documented $[13,75,79,93,120,121]$. However, a limited number of studies suggest that venom from endoparasitoid species devoid of symbiotic viruses may alone suppress encapsulation reactions of the host hemocytes.

We recently described how parasitism and venom from $P$. turionellae that lacks symbiotic viruses affected the encapsulation and melanization rates of G. mellonella larvae and pupae [72]. In the experiments, DEAE-Sephadex A-25 beads were used as encapsulation targets. The removed beads from the insects scored as negative (no, or only a few hemocytes attached to beads), weak (2-10 layers of hemocytes around beads), and strong (more than 10 layers of hemocytes around beads) (Figure 5) [72, 119]. The analysis of the Sephadex A-25 beads injected in different developmental stages of G. mellonella revealed that a strong encapsulation reaction can occur in the pupal stage but the encapsulation material was less compacted compared to larvae [72]. Our investigation revealed that the number of beads strongly encapsulated and melanized was reduced by more than $50 \%$ at 4 and $24 \mathrm{~h}$ after injection of venom in pupae (0.05 VRE) and in larvae (0.5 VRE) [72]. Similar results were also obtained when beads were recovered from parasitized pupae indicating that parasitization by $P$. turionellae suppressed hemocyte-mediated encapsulation in G. mellonella [72]. Our results are similar to those reported in the host parasitoid systems that lack symbiotic viruses where venom was shown to prevent encapsulation (Table 2). The efficacy of encapsulation response is known to be influenced by a number of parameters, including the number of hemocytes available and their ability to spread $[115,120$, 121]. Thus changes in the spreading ability of hemocytes caused by venom are also shown in Table 2. Parasitism by an ectoparasitoid $N$. vitripennis was showed to have an impact on host hemocytes that plasmatocytes and granulocytes lost the ability to spread [26]. Similarly venom from the endoparasitoid $P$. hypochondriaca affects the spreading of plasmatocytes [10]. In the $P$. puparum/P. rapae and $P$. puparum $/ P$. xuthus systems the spreading of hemocytes was greatly inhibited with venom resulting from the inhibition of plasmatocyte pseudopod formation [23, 78].

Since $P$. turionellae and other endoparasitoid species specially emphasized on in this paper are devoid of any VLPs or PDVs, it was expected that components of the wasp venoms could contribute towards avoidance of encapsulation by the parasitoids. However, limited numbers of endoparasitoid venom proteins have been reported to affect the hemocyte behavior of insects [122]. For example, a single venom protein $\mathrm{Vn} .11$ with a mean of $24.1 \mathrm{kDa}$ in size has been isolated from P. puparum venom [24]. The protein was identified as an immune suppressive factor, and was suggested to affect the spreading and encapsulation ability of host hemocytes [24]. P. puparum venom was also shown to influence gene expression in host hemocytes and fat body [123]. Venom treatments led to reductions in expression of a large number of genes acting especially in immunity [123]. Biochemically isolated venom proteins Vpr1 and Vpr3 from $P$. hypochondriaca were shown to suppress encapsulation 
TABLE 2: Changes in the encapsulation and spreading ability of hemocytes induced by parasitism and venom from the parasitoids devoid of symbiotic viruses.

\begin{tabular}{|c|c|c|c|c|c|}
\hline \multirow{2}{*}{ Parasitoid } & \multirow{2}{*}{ Host } & \multirow{2}{*}{ Treatments } & \multicolumn{2}{|c|}{ Effects observed } & \multirow{2}{*}{ Ref. } \\
\hline & & & Hemocyte encapsulation & $\begin{array}{l}\text { Cell } \\
\text { spreading }\end{array}$ & \\
\hline Pimpla turionellae & Galleria mellonella & $\begin{array}{l}\text { Parasitized } \\
\text { Venom }\end{array}$ & $\begin{array}{l}\text { Reduced } \\
\text { Reduced }\end{array}$ & & {$[72]$} \\
\hline Pimpla turionellae & $\begin{array}{l}\text { Cells derived from Trichoplusia ni } \\
\text { and Aedes aegypti }\end{array}$ & Venom & & Reduced & [25] \\
\hline Nasonia vitripennis & Sarcophaga bullata & Venom & & Reduced & [26] \\
\hline $\begin{array}{l}\text { Asobara citri } \\
\text { Asobara tabida }\end{array}$ & $\begin{array}{l}\text { Drosophila melanogaster } \\
\text { Drosophila melanogaster }\end{array}$ & $\begin{array}{l}\text { Parasitized } \\
\text { Parasitized }\end{array}$ & $\begin{array}{l}\text { Reduced } \\
\text { No effect }\end{array}$ & & {$[28]$} \\
\hline \multirow{3}{*}{ Asobara tabida } & $\begin{array}{l}\text { Drosophila sechellia } \\
\text { Drosophiala melanogaster }\end{array}$ & Parasitized & Slight ability to encapsulate & & \multirow{3}{*}{29} \\
\hline & $\begin{array}{l}\text { Drosophila mauritiana Drosophila } \\
\text { yakuba }\end{array}$ & Parasitized & $\begin{array}{l}\text { Medium ability to } \\
\text { encapsulate }\end{array}$ & & \\
\hline & $\begin{array}{l}\text { Drosophila teissieri } \\
\text { Drosophila simulans }\end{array}$ & Parasitized & High ability to encapsulate & & \\
\hline Asobara japonica & Drosophila melanogaster & Parasitized & Reduced & & [30] \\
\hline Pimpla hypochondriaca & Lacanobia Oleracea (larval stage) & Venom & Reduced & Reduced & [10] \\
\hline Pimpla hypochondriaca & Lacanobia Oleracea (pupal stage) & Venom & Reduced & & [54] \\
\hline Pteromalus puparum & Pieris rapae & Venom & Reduced & Reduced & [23] \\
\hline Pteromalus puparum & $\begin{array}{l}\text { Pieris rapae } \\
\text { Papilio xuthus }\end{array}$ & Venom & & Reduced & {$[78]$} \\
\hline Pteromalus puparum & Pieris rapae & Venom & Reduced & & [88] \\
\hline
\end{tabular}

responses in a lepidopteran larva in vivo and to inhibit the spreading and aggregation of insect hemocytes maintained in vitro $[119,122]$. These works also represent for the first time that the genes for such proteins (i.e., Vpr1 and Vpr3) have been identified from $P$. hypochondriaca and that a function can be applied to proteins produced from the Vpr1 and Vpr3 genes $[119,122]$. In $C$. rubecula venom that contains PDV, a $58 \mathrm{kDa}$ calreticulin-like protein was found to inhibit the spreading behavior of the host hemocytes and thus preventing the encapsulation of the developing parasitoid in the host [124]. Despite the considerable attention given to determine the role of venoms in suppression of host encapsulation response, the modes of action or molecular target sites of parasitoid venom components in hostendoparasitoid systems is still not well known and is in need of further investigation.

\section{Conclusion Remarks}

In certain host parasitoid systems, venom that is injected prior to oviposition can elicit a diverse range of host responses including suppression of host immune responses. As discussed in this paper, venom can lead to a reduction of hemocytes in circulation, and this phenomenon was thought to be caused by cell death via apoptosis. Also, we have provided an overview of current knowledge on the effects of venom on hemocytic encapsulation responses in different developmental stages of the host insects. Because endoparasitoid species specially emphasized on in this paper are devoid of any VLPs or PDVs, it was expected that components of the wasp venoms could contribute to avoidance of encapsulation by the parasitoids. A series of potential candidates in venom that has obvious potential roles in venom-mediated immunosuppression have been identified in several wasp venoms. However the information presented in this section lacks many mechanistic details of how venom components suppress hemocyte-mediated immune responses at the cellular level. The characterization of venom proteins and comparative genomic approaches should provide insights into their possible mechanisms of action in host-parasite interactions at molecular level. This represents an area of new studies associated with host regulatory factors in parasitoid venom that needs further investigations.

\section{References}

[1] P. Jiravanichpaisal, B. L. Lee, and K. Söderhäll, "Cell-mediated immunity in arthropods: hematopoiesis, coagulation, melanization and opsonization," Immunobiology, vol. 211, no. 4, pp. 213-236, 2006.

[2] M. D. Lavine and M. R. Strand, "Insect hemocytes and their role in immunity," Insect Biochemistry and Molecular Biology, vol. 32, no. 10, pp. 1295-1309, 2002.

[3] M. R. Strand, "The insect cellular immune response," Insect Science, vol. 15, no. 1, pp. 1-14, 2008.

[4] J. Kurtz, "Specific memory within innate immune systems," Trends in Immunology, vol. 26, no. 4, pp. 186-192, 2005.

[5] O. Schmidt, U. Theopold, and M. Strand, "Innate immunity and its evasion and suppression by hymenopteran endoparasitoids," BioEssays, vol. 23, no. 4, pp. 344-351, 2001. 
[6] P. Vilmos and É. Kurucz, "Insect immunity: evolutionary roots of the mammalian innate immune system," Immunology Letters, vol. 62, no. 2, pp. 59-66, 1998.

[7] J. García-Lara, A. J. Needham, and S. J. Foster, "Invertebrates as animal models for Staphylococcus aureus pathogenesis: a window into host-pathogen interaction," FEMS Immunology and Medical Microbiology, vol. 43, no. 3, pp. 311-323, 2005.

[8] C. Ribeiro and M. Brehélin, "Insect haemocytes: what type of cell is that?" Journal of Insect Physiology, vol. 52, no. 5, pp. 417-429, 2006.

[9] S. N. Thompson, "Nutrition and culture of entomophagous insects," Annual Review of Entomology, vol. 44, pp. 561-592, 1999.

[10] E. H. Richards and N. M. Parkinson, "Venom from the endoparasitic wasp Pimpla hypochondriaca adversely affects the morphology, viability, and immune function of hemocytes from larvae of the tomato moth, Lacanobia oleracea," Journal of Invertebrate Pathology, vol. 76, no. 1, pp. 33-42, 2000.

[11] M. W. Turnbull, S. B. Martin, and B. A. Webb, "Quantitative analysis of hemocyte morphological abnormalities associated with Campoletis sonorensis parasitization," Journal of Insect Science, vol. 4, pp. 11-26, 2004.

[12] F. Pennacchio, A. Tranfaglia, and C. Malva, "Host-parasitoid antagonism in insects: new opportunities for pest control?" Agro Food Industry Hi-Tech, vol. 14, no. 4, pp. 53-56, 2003.

[13] S. Luckhart and B. A. Webb, "Interaction of a wasp ovarian protein and polydnavirus in host immune suppression," Developmental and Comparative Immunology, vol. 20, no. 1, pp. 1-21, 1996.

[14] K. Luo and Y. Pang, "Spodoptera litura multicapsid nucleopolyhedrovirus inhibits Microplitis bicoloratus polydnavirusinduced host granulocytes apoptosis," Journal of Insect Physiology, vol. 52, no. 8, pp. 795-806, 2006.

[15] D. B. Stoltz and D. Guzo, "Apparent haemocytic transformations associated with parasitoid-induced inhibition of immunity in Malacosoma disstria larvae," Journal of Insect Physiology, vol. 32, no. 4, pp. 377-388, 1986.

[16] D. H. Davies, M. R. Strand, and S. B. Vinson, "Changes in differential haemocyte count and in vitro behaviour of plasmatocytes from host Heliothis virescens caused by Campoletis sonorensis polydnavirus," Journal of Insect Physiology, vol. 33, no. 3, pp. 143-153, 1987.

[17] R. M. Rizki and T. M. Rizki, "Parasitoid virus-like particles destroy Drosophila cellular immunity," Proceedings of the National Academy of Sciences of the United States of America, vol. 87, no. 21, pp. 8388-8392, 1990.

[18] B. A. Webb and S. Luckhart, "Evidence for an early immunosuppressive role for related Campoletis sonorensis venom and ovarian proteins in Heliothis virescens," Archives of Insect Biochemistry and Physiology, vol. 26, no. 2-3, pp. 147-163, 1994.

[19] N. E. Beckage and D. B. Gelman, "Wasp parasitoid disruption of host development: implications for new biologically based strategies for insect control," Annual Review of Entomology, vol. 49, pp. 299-330, 2004.

[20] T. Tanaka, "Effect of the venom of the endoparasitoid, Apanteles kariyai Watanabe, on the cellular defence reaction of the host, Pseudaletia separata Walker," Journal of Insect Physiology, vol. 33, no. 6, pp. 413-420, 1987.

[21] P. Gupta and S. M. Ferkovich, "Interaction of calyx fluid and venom from Microplitis croceipes (Braconidae) on developmental disruption of the natural host, Heliocoverpa zea, and two atypical hosts, Galleria mellonella and Spodoptera exigua," Journal of Insect Physiology, vol. 44, no. 9, pp. 713719, 1998.

[22] N. M. Parkinson and R. J. Weaver, "Noxious components of venom from the pupa-specific parasitoid Pimpla hypochondriaca," Journal of Invertebrate Pathology, vol. 73, no. 1, pp. 74-83, 1999.

[23] J. Cai, G. Y. Ye, and C. Hu, "Parasitism of Pieris rapae (Lepidoptera: Pieridae) by a pupal endoparasitoid, Pteromalus puparum (Hymenoptera: Pteromalidae): effects of parasitization and venom on host hemocytes," Journal of Insect Physiology, vol. 50, no. 4, pp. 315-322, 2004.

[24] M. L. Wu, G. Y. Ye, J. Y. Zhu, X. X. Chen, and C. Hu, "Isolation and characterization of an immunosuppressive protein from venom of the pupa-specific endoparasitoid Pteromalus puparum," Journal of Invertebrate Pathology, vol. 99, no. 2, pp. 186-191, 2008.

[25] E. Ergin, F. Uçkan, D. B. Rivers, and O. Sak, "In vivo and in vitro activity of venom from the endoparasitic wasp Pimpla turionellae (L.) (Hymenoptera: Ichneumonidae)," Archives of Insect Biochemistry and Physiology, vol. 61, no. 2, pp. 87-97, 2006.

[26] D. B. Rivers, L. Ruggiero, and M. Hayes, "The ectoparasitic wasp Nasonia vitripennis (Walker) (Hymenoptera: Pteromalidae) differentially affects cells mediating the immune response of its flesh fly host, Sarcophaga bullata Parker (Diptera: Sarcophagidae)," Journal of Insect Physiology, vol. 48, no. 11, pp. 1053-1064, 2002.

[27] D. B. Rivers, F. Uçkan, E. Ergin, and D. A. Keefer, "Pathological and ultrastructural changes in cultured cells induced by venom from the ectoparasitic wasp Nasonia vitripennis (Walker) (Hymenoptera: Pteromalidae)," Journal of Insect Physiology, vol. 56, no. 12, pp. 1935-1948, 2010.

[28] S. J. M. Moreau, P. Eslin, P. Giordanengo, and G. Doury, "Comparative study of the strategies evolved by two parasitoids of the genus Asobara to avoid the immune response of the host, Drosophila melanogaster," Developmental and Comparative Immunology, vol. 27, no. 4, pp. 273-282, 2003.

[29] P. Eslin and G. Prevost, "Variation in Drosophila concentration of haemocytes associated with different ability to encapsulate Asobara tabida larval parasitoid," Journal of Insect Physiology, vol. 42, no. 6, pp. 549-555, 1996.

[30] A. D. N. Mabiala-Moundoungou, G. Doury, P. Eslin, A. Cherqui, and G. Prévost, "Deadly venom of Asobara japonica parasitoid needs ovarian antidote to regulate host physiology," Journal of Insect Physiology, vol. 56, no. 1, pp. 35-41, 2010.

[31] D. B. Rivers and D. L. Denlinger, "Developmental fate of the flesh fly, Sarcophaga bullata, envenomated by the pupal ectoparasitoid, Nasonia vitripennis," Journal of Insect Physiology, vol. 40, no. 2, pp. 121-127, 1994.

[32] D. B. Rivers and D. L. Denlinger, "Redirection of metabolism in the flesh fly, Sarcophaga bullata, following envenomation by the ectoparasitoid Nasonia vitripennis and correlation of metabolic effects with the diapause status of the host," Journal of Insect Physiology, vol. 40, no. 3, pp. 207-215, 1994.

[33] T. A. Coudron and S. L. Brandt, "Characteristics of a developmental arrestant in the venom of the ectoparasitoid wasp Euplectrus comstocki," Toxicon, vol. 34, no. 11-12, pp. 14311441, 1996.

[34] T. A. Coudron, M. M. K. Wright, B. Puttler, S. L. Brandt, and W. C. Rice, "Effect of the ectoparasite Necremnus breviramulus (Hymenoptera: Eulophidae) and its venom on natural and factitious hosts," Annals of the Entomological Society of America, vol. 93, no. 4, pp. 890-897, 2000. 
[35] M. C. Digilio, F. Pennacchio, and E. Tremblay, "Host regulation effects of ovary fluid and venom of Aphidius ervi (Hymenoptera: Braconidae)," Journal of Insect Physiology, vol. 44, no. 9, pp. 779-784, 1998.

[36] D. B. Rivers, M. Genco, and R. A. Sanchez, "In vitro analysis of venom from the wasp Nasonia vitripennis: susceptibility of different cell lines and venom-induced changes in plasma membrane permeability," In Vitro Cellular and Developmental Biology-Animal, vol. 35, no. 2, pp. 102-110, 1999.

[37] D. B. Rivers, W. F. Hink, and D. L. Denlinger, "Toxicity of the venom from Nasonia vitripennis (Hymenoptera: Pteromalidae) toward fly hosts, nontarget insects, different developmental stages, and cultured insect cells," Toxicon, vol. 31, no. 6, pp. 755-765, 1993.

[38] D. B. Rivers, M. M. Rocco, and A. R. Frayha, "Venom from the ectoparasitic wasp Nasonia vitripennis increases $\mathrm{Na}^{+}$ influx and activates phospholipase $\mathrm{C}$ and phospholipase A2 dependent signal transduction pathways in cultured insect cells," Toxicon, vol. 40, no. 1, pp. 9-21, 2002.

[39] D. B. Rivers, F. Uckan, and E. Ergin, "Characterization and biochemical analyses of venom from the ectoparasitic wasp Nasonia vitripennis (Walker) (Hymenoptera: Pteromalidae)," Archives of Insect Biochemistry and Physiology, vol. 61, no. 1, pp. 24-41, 2006.

[40] J. Leluk, J. Schmidt, and D. Jones, "Comparative studies on the protein composition of hymenopteran venom reservoirs," Toxicon, vol. 27, no. 1, pp. 105-114, 1989.

[41] W. S. Skinner, P. A. Dennis, and G. B. Quistad, "Partial characterization of toxins from Goniozus legneri (Hymenoptera: Braconidae)," Journal of Economic Entomology, vol. 83, pp. 733-736, 1990.

[42] F. Sanchez, M. Blanca, A. Miranda et al., "Comparison of Vespula germanica venoms obtained from different sources," International Archives of Allergy and Immunology, vol. 104, no. 4, pp. 385-389, 1994.

[43] T. Yasuhara, P. Mantel, T. Nakajima, and T. Piek, “Two kinins isolated from an extract of the venom reservoirs of the solitary wasp Megascolia flavifrons," Toxicon, vol. 25, no. 5, pp. 527-535, 1987.

[44] T. Toki, T. Yasuhara, and T. Nakajima, "Isolation and sequential analysis of peptides on the venom sac of Parapolybia indica," Japanese Journal of Sanitary Zoology, vol. 39, pp. 105111, 1988.

[45] D. Jones and J. Leluk, "Venom proteins of the endoparasitic wasp Chelonus near curvimaculatus: characterization of the major components," Archives of Insect Biochemistry and Physiology, vol. 13, pp. 95-106, 1990.

[46] T. H. Jones, M. S. Blum, and H. G. Robertson, "Novel dialkylpiperidines in the venom of the ant Monomorium delagoense," Journal of Natural Products, vol. 53, no. 2, pp. 429-435, 1990.

[47] G. B. Quistad, Nguyen Quyen, P. Bernasconi, and D. J. Leisy, "Purification and characterization of insecticidal toxins from venom glands of the parasitic wasp, Bracon hebetor," Insect Biochemistry and Molecular Biology, vol. 24, no. 10, pp. 955961, 1994.

[48] G. Doury, Y. Bigot, and G. Periquet, "Physiological and biochemical analysis of factors in the female venom gland and larval salivary secretions of the ectoparasitoid wasp Eupelmus orientalis," Journal of Insect Physiology, vol. 43, no. 1, pp. 69-81, 1997.

[49] A. Hochuli, R. Pfister-Wilhelm, and B. Lanzrein, "Analysis of endoparasitoid-released proteins and their effects on host development in the system Chelonus inanitus (Braconidae)Spodoptera littoralis (Noctuidae)," Journal of Insect Physiology, vol. 45, no. 9, pp. 823-833, 1999.

[50] K. Konno, M. Hisada, H. Naoki et al., "Structure and biological activities of eumenine mastoparan-AF (EMP-AF), a new mast cell degranulating peptide in the venom of the solitary wasp (Anterhynchium flavomarginatum micado)," Toxicon, vol. 38, no. 11, pp. 1505-1515, 2000.

[51] N. Parkinson, I. Smith, R. Weaver, and J. P. Edwards, "A new form of arthropod phenoloxidase is abundant in venom of the parasitoid wasp Pimpla hypochondriaca," Insect Biochemistry and Molecular Biology, vol. 31, no. 1, pp. 57-63, 2001.

[52] A. Hochuli and B. Lanzrein, "Characterization of a $212 \mathrm{kD}$ protein, released into the host by the larva of the endoparasitoid Chelonus inanitus (Hymenoptera, Braconidae)," Journal of Insect Physiology, vol. 47, no. 11, pp. 1313-1319, 2001.

[53] N. Parkinson, C. Conyers, and I. Smith, "A venom protein from the endoparasitoid wasp Pimpla hypochondriaca is similar to snake venom reprolysin-type metalloproteases," Journal of Invertebrate Pathology, vol. 79, no. 2, pp. 129-131, 2002.

[54] N. Parkinson, E. H. Richards, C. Conyers, I. Smith, and J. P. Edwards, "Analysis of venom constituents from the parasitoid wasp Pimpla hypochondriaca and cloning of a cDNA encoding a venom protein," Insect Biochemistry and Molecular Biology, vol. 32, no. 7, pp. 729-735, 2002.

[55] N. Parkinson, I. Smith, N. Audsley, and J. P. Edwards, "Purification of pimplin, a paralytic heterodimeric polypeptide from venom of the parasitoid wasp Pimpla hypochondriaca, and cloning of the cDNA encoding one of the subunits," Insect Biochemistry and Molecular Biology, vol. 32, no. 12, pp. 1769-1773, 2002.

[56] K. Konno, M. S. Palma, I. Y. Hitara, M. A. Juliano, L. Juliano, and T. Yasuhara, "Identification of bradykinins in solitary wasp venoms," Toxicon, vol. 40, no. 3, pp. 309-312, 2001.

[57] N. M. Parkinson, C. M. Conyers, J. N. Keen, A. D. MacNicoll, I. Smith, and R. J. Weaver, "cDNAs encoding large venom proteins from the parasitoid wasp Pimpla hypochondriaca identified by random sequence analysis," Comparative Biochemistry and Physiology Part C, vol. 134, no. 4, pp. 513-520, 2003.

[58] S. Asgari, G. Zhang, R. Zareie, and O. Schmidt, "A serine proteinase homolog venom protein from an endoparasitoid wasp inhibits melanization of the host hemolymph," Insect Biochemistry and Molecular Biology, vol. 33, no. 10, pp. 10171024, 2003.

[59] N. M. Parkinson, C. Conyers, J. Keen et al., "Towards a comprehensive view of the primary structure of venom proteins from the parasitoid wasp Pimpla hypochondriaca," Insect Biochemistry and Molecular Biology, vol. 34, no. 6, pp. 565-571, 2004.

[60] S. J. M. Moreau and S. Guillot, "Advances and prospects on biosynthesis, structures and functions of venom proteins from parasitic wasps," Insect Biochemistry and Molecular Biology, vol. 35, no. 11, pp. 1209-1223, 2005.

[61] M. Abt and D. B. Rivers, "Characterization of phenoloxidase activity in venom from the ectoparasitoid Nasonia vitripennis (Walker) (Hymenoptera: Pteromalidae)," Journal of Invertebrate Pathology, vol. 94, no. 2, pp. 108-118, 2007.

[62] D. Drenth, "Susceptibility of different species of insects to an extract of the venom gland of the wasp Microbracon hebetor (Say)," Toxicon, vol. 12, no. 2, pp. 189-192, 1974. 
[63] Y. Nakamatsu and T. Tanaka, "Venom of ectoparasitoid, Euplectrus sp. near plathypenae (Hymenoptera: Eulophidae) regulates the physiological state of Pseudaletia separata (Lepidoptera: Noctuidae) host as a food resource," Journal of Insect Physiology, vol. 49, no. 2, pp. 149-159, 2003.

[64] R. A. Wharton, "Bionomics of the braconidae," Annual Review of Entomology, vol. 38, no. 1, pp. 121-143, 1993.

[65] Y. Nakamatsu, Y. Gyotoku, and T. Tanaka, "The endoparasitoid Cotesia kariyai (Ck) regulates the growth and metabolic efficiency of Pseudaletia separata larvae by venom and Ck polydnavirus," Journal of Insect Physiology, vol. 47, no. 6, pp. 573-584, 2001.

[66] E. P. Masler and E. S. Kovaleva, "Inhibition of larval growth in the gypsy moth (Lepidoptera: Lymantriidae) by venom from the parasitic wasp Microbracon hebetor (Hymenoptera: Braconidae)," Journal of Entomological Science, vol. 34, no. 4, pp. 435-444, 1999.

[67] E. Ergin, F. Uçkan, and D. B. Rivers, "Biochemical characterization and mode of action of venom from the endoparasitoid wasp Pimpla turionellae," in Recent Advances in the Biochemistry, Toxicity, and Mode of Action of Parasitic Wasp Venoms, D. Rivers and J. Yoder, Eds., chapter 8, pp. 129-160, Research Signpost, Kerala, India, 2007.

[68] M. C. Digilio, N. Isidoro, E. Tremblay, and F. Pennacchio, "Host castration by Aphidius ervi venom proteins," Journal of Insect Physiology, vol. 46, no. 6, pp. 1041-1050, 2000.

[69] M. P. Dani, E. H. Richards, R. E. Isaac, and J. P. Edwards, "Antibacterial and proteolytic activity in venom from the endoparasitic wasp Pimpla hypochondriaca (Hymenoptera: Ichneumonidae)," Journal of Insect Physiology, vol. 49, no. 10, pp. 945-954, 2003.

[70] E. H. Richards and J. P. Edwards, "Parasitization of Lacanobia oleracea (Lepidoptera: Noctuidae) by the ectoparasitc wasp, Eulophus pennicornis effects of parasitization, venom and starvation on host haemocytes," Journal of Insect Physiology, vol. 45, no. 12, pp. 1073-1083, 1999.

[71] A. Er, F. Uçkan, D. B. Rivers, E. Ergin, and O. Sak, "Effects of parasitization and envenomation by the endoparasitic wasp Pimpla turionellae (Hymenoptera: Ichneumonidae) on hemocyte numbers, morphology, and viability of its host Galleria mellonella lepidoptera: Pyralidae)," Annals of the Entomological Society of America, vol. 103, no. 2, pp. 273-282, 2010.

[72] F. Uçkan, A. Er, and E. Ergin, "Levels of encapsulation and melanization in Galleria mellonella (Lepidoptera: Pyralidae) parasitized and envenomated by Pimpla turionellae (Hymenoptera: Ichneumonidae)," Journal of Applied Entomology, vol. 134, no. 9-10, pp. 718-726, 2010.

[73] İ. A. Kansu and A. Ugur, "Pimpla turionellae (L.) (Hym., Ichneumonidae) ile konukçusu bazı lepidopter pupaları arasındaki biyolojik ilişkiler üzerinde araştırmalar," Doğa Bilim Dergisi, vol. D2, no. 8, pp. 160-173, 1984.

[74] M. B. Mochiah, A. J. Ngi-Song, W. A. Overholt, and M. Botchey, "Variation in total and differential haemocyte count of Busseola fusca (Lepidoptera: Noctuidae) parasitized by two biotypes of Cotesia sesamiae (Hymenoptera: Braconidae) and larval growth responses," Environmental Entomology, vol. 32, no. 2, pp. 247-255, 2003.

[75] A. M. A. Ibrahim and Y. Kim, "Parasitism by Cotesia plutellae alters the hemocyte population and immunological function of the diamondback moth, Plutella xylostella," Journal of Insect Physiology, vol. 52, no. 9, pp. 943-950, 2006.
[76] Z. Zhang, G. Y. Ye, J. Cai, and C. Hu, "Comparative venom toxicity between Pteromalus puparum and Nasonia vitripennis (Hymenoptera: Pteromalidae) toward the hemocytes of their natural hosts, non-target insects and cultured insect cells," Toxicon, vol. 46, no. 3, pp. 337-349, 2005.

[77] R. X. Yu, Y. F. Chen, X. X. Chen, F. Huang, Y. G. Lou, and S. S. Liu, "Effects of venom/calyx fluid from the endoparasitic wasp Cotesia plutellae on the hemocytes of its host Plutella xylostella in vitro," Journal of Insect Physiology, vol. 53, no. 1, pp. 22-29, 2007.

[78] Z. Zhang, G. Y. Ye, H. X. Wang, J. Cai, and C. Hu, "Changes of total number and composition of hemocytes from Pieris rapae and Papilio polytes after parasitism by Pteromalus puparum (Hymenoptera: Pteromalidae)," Acta Phytophylacica Sinica, vol. 32, pp. 158-162, 2005.

[79] H. Kitano, "The role of Apanteles glomeratus venom in the defensive response of its host, Pieris rapae crucivora," Journal of Insect Physiology, vol. 32, no. 4, pp. 369-375, 1986.

[80] T. Tanaka, "Calyx and venom fluids of Apanteles kariyai as factors that prolong larval period of the host, Pseudaletia separata," Annals of the Entomological Society of America, vol. 80, pp. 530-533, 1987.

[81] M. R. Strand and B. A. Dover, "Developmental disruption of Pseudoplusia includens and Heliothis virescens larvae by the calyx fluid and venom of Microplitis demolitor," Archives of Insect Biochemistry and Physiology, vol. 18, no. 3, pp. 131145, 1991.

[82] A. Er, F. Uçkan, D. B. Rivers, and O. Sak, "Cytotoxic effects of parasitism and application of venom from the endoparasitoid Pimpla turionellae on hemocytes of the host Galleria mellonella," Journal of Applied Entomology, vol. 135, no. 3, pp. 225-236, 2011.

[83] T. Teramoto and T. Tanaka, "Mechanism of reduction in the number of the circulating hemocytes in the Pseudaletia separata host parasitized by Cotesia kariyai," Journal of Insect Physiology, vol. 50, no. 12, pp. 1103-1111, 2004.

[84] E. H. Richards and M. P. Dani, "Venom-induced apoptosis of insect hemocytes," in Recent Advances in the Biochemistry, Toxicity, and Mode of Action of Parasitic Wasp Venoms, D. B. Rivers and J. A. Yoder, Eds., pp. 19-36, Research Sign Post, Kerala, India, 2007.

[85] D. B. Rivers, E. Ergin, and F. Uçkan, "Cell death in the host-parasitoid relationship," in New Developments in Cell Apoptosis Research, A. J. Corvin, Ed., pp. 69-96, Nova Science Publishers, New York, NY, USA, 2007.

[86] M. Cendoroglo, B. L. Jaber, V. S. Balakrishnan, M. Perianayagam, A. J. King, and B. J. G. Pereira, "Neutrophil apoptosis and dysfunction in uremia," Journal of the American Society of Nephrology, vol. 10, no. 1, pp. 93-100, 1999.

[87] B. Kosmider, E. Zyner, R. Osiecka, and J. Ochocki, "Induction of apoptosis and necrosis in A549 cells by the cis- $\mathrm{Pt}(\mathrm{II})$ complex of 3-aminoflavone in comparison with cis-DDP," Mutation Research, vol. 563, no. 1, pp. 61-70, 2004.

[88] J. Y. Zhu, Q. Fang, L. Wang, C. Hu, and G. Y. Ye, "Proteomic analysis of the venom from the endoparasitoid wasp Pteromalus puparum (Hymenoptera: Pteromalidae)," Archives of Insect Biochemistry and Physiology, vol. 75, no. 1, pp. 28-44, 2010.

[89] S. Asgari, "Venom proteins from polydnavirus-producing endoparasitoids: their role in host-parasite interactions," Archives of Insect Biochemistry and Physiology, vol. 61, no. 3, pp. 146-156, 2006. 
[90] M. R. Strand and L. L. Pech, "Microplitis demolitor polydnavirus induces apoptosis of a specific haemocyte morphotype in Pseudoplusia includens," Journal of General Virology, vol. 76, no. 2, pp. 283-291, 1995.

[91] P. O. Lawrence, "Morphogenesis and cytopathic effects of the Diachasmimorpha longicaudata entomopoxvirus in host haemocytes," Journal of Insect Physiology, vol. 51, no. 2, pp. 221-233, 2005.

[92] R. Ferrarese, M. Brivio, T. Congiu et al., "Early suppression of immune response in Heliothis virescens larvae by the endophagous parasitoid Toxoneuron nigriceps," ISJ, vol. 2, pp. 60-68, 2005.

[93] M. Suzuki and T. Tanaka, "Virus-like particles in venom of Meteorus pulchricornis induce host hemocyte apoptosis," Journal of Insect Physiology, vol. 52, no. 6, pp. 602-613, 2006.

[94] P. Nicotera, P. Hartzell, G. Davis, and S. Orrenius, "The formation of plasma membrane blebs in hepatocytes exposed to agents that increase cytosolic $\mathrm{Ca}^{2+}$ is mediated by the activation of a non-lysosomal proteolytic system," FEBS Letters, vol. 209, no. 1, pp. 139-144, 1986.

[95] P. C. Phelps, M. W. Smith, and B. F. Trump, "Cytosolic ionized calcium and bleb formation after acute cell injury of cultured rabbit renal tubule cells," Laboratory Investigation, vol. 60, no. 5, pp. 630-642, 1989.

[96] D. A. Troyer, J. I. Kreisberg, and M. A. Venkatachalam, "Lipid alterations in LLC-PK1 cells exposed to mercuric chloride," Kidney International, vol. 29, no. 2, pp. 530-538, 1986.

[97] J. F. Pérez, M. E. Chemello, F. Liprandi, M. C. Ruiz, and F. Michelangeli, "Oncosis in MA104 cells is induced by rotavirus infection through an increase in intracellular $\mathrm{Ca}^{2+}$ concentration," Virology, vol. 252, no. 1, pp. 17-27, 1998.

[98] D. B. Rivers, M. P. Dani, and E. H. Richards, "The mode of action of venom from the endoparasitic wasp Pimpla hypochondriaca (Hymenoptera: Ichneumonidae) involves $\mathrm{Ca}^{+2}$-dependent cell death pathways," Archives of Insect Biochemistry and Physiology, vol. 71, no. 3, pp. 173-190, 2009.

[99] D. B. Rivers and A. Brogan, "Venom glands from the ectoparasitoid Nasonia vitripennis (Walker) (Hymenoptera: Pteromalidae) produce a calreticulin-like protein that functions in developmental arrest and cell death in the flesh fly host. Sarcophaga bullata Parker (Diptera: Sarcophagidae)," in Insect Physiology: New Research, R. Maes, Ed., pp. 259-278, NOVA Scientific, New York, NY, USA, 2008.

[100] D. C. de Graaf, M. Aerts, M. Brunain et al., "Insights into the venom composition of the ectoparasitoid wasp Nasonia vitripennis from bioinformatic and proteomic studies," Insect Molecular Biology, vol. 19, no. 1, pp. 11-26, 2010.

[101] M. Michalak, E. F. Corbett, N. Mesaeli, K. Nakamura, and M. Opas, "Calreticulin: one protein, one gene, many functions," Biochemical Journal, vol. 344, no. 2, pp. 281-292, 1999.

[102] E. L. Danneels, D. B. Rivers, and D. C. de Graaf, "Venom proteins of the parasitoid wasp Nasonia vitripennis: recent discovery of an untapped pharmacopee," Toxins, vol. 2, no. 4, pp. 494-516, 2010.

[103] C. Díaz, L. Valverde, O. Brenes, A. Rucavado, and J. M. Gutiérrez, "Characterization of events associated with apoptosis/anoikis induced by snake venom metalloproteinase BaP1 on human endothelial cells," Journal of Cellular Biochemistry, vol. 94, no. 3, pp. 520-528, 2005.

[104] I. Tanjoni, R. Weinlich, M. S. Della-Casa et al., "Jararhagin, a snake venom metalloproteinase, induces a specialized form of apoptosis (anoikis) selective to endothelial cells," Apoptosis, vol. 10, no. 4, pp. 851-861, 2005.
[105] J. C. JonesA. S. Gordon, "Hematopoiesis in insects," in Regulation of Hematopoieis, pp. 7-65, Appleton Press, New York, NY, USA, 1970.

[106] N. A. Ratcliffe, A. F. Rowley, S. W. Fitzgerald, and C. P. Rhodes, "Invertebrate immunity: basic concepts and recent advances," International Review of Cytology, vol. 97, pp. 184350, 1985.

[107] M. Shapiro, "Changes in the haemocyte population of the wax moth, Galleria mellonella, during wound healing," Journal of Insect Physiology, vol. 14, no. 12, pp. 1725-1733, 1968.

[108] J. W. Arnold and C. F. Hinks, "Haemopoiesis in Lepidoptera. I. A note on the multiplication of spherule cells and granular haemocytes," Canadian Journal of Zoology, vol. 61, pp. 275$277,1976$.

[109] J. Beaulaton, "Hemocytes and hemocytopoiesis in Silkworms," Biochimie, vol. 61, no. 2, pp. 157-164, 1979.

[110] J. P. Gillespie, M. R. Kanost, and T. Trenczek, "Biological mediators of insect immunity," Annual Review of Entomology, vol. 42, pp. 611-643, 1997.

[111] L. L. Pech and M. R. Strand, "Plasmatocytes from the moth Pseudoplusia includens induce apoptosis of granular cells," Journal of Insect Physiology, vol. 46, no. 12, pp. 1565-1573, 2000.

[112] N. A. Ratcliffe, "Cellular defense responses of insects: unresolved problems," in Parasites and Pathogens of Insects, N. E. Beckage, S. N. Thompson, and B. A. Federci, Eds., vol. 1, pp. 267-304, Academic Press, New York, NY, USA, 1993.

[113] J. B. Nardi, B. Pilas, E. Ujhelyi, K. Garsha, and M. R. Kanost, "Hematopoietic organs of Manduca sexta and hemocyte lineages," Development Genes and Evolution, vol. 213, no. 10, pp. 477-491, 2003.

[114] A. R. Schmit and N. A. Ratcliffe, "The encapsulation of Araldite implants and recognition of foreignness in Clitumnus extradentatus," Journal of Insect Physiology, vol. 24, no. 6-7, pp. 511-521, 1978.

[115] M. R. Strand and L. L. Pech, "Immunological basis for compatibility in parasitoid-host relationships," Annual Review of Entomology, vol. 40, pp. 31-56, 1995.

[116] L. L. Pech and M. R. Strand, "Granular cells are required for encapsulation of foreign targets by insect haemocytes," Journal of Cell Science, vol. 109, no. 8, pp. 2053-2060, 1996.

[117] A. J. Nappi, E. Vass, F. Frey, and Y. Carton, "Superoxide anion generation in Drosophila during melanotic encapsulation of parasites," European Journal of Cell Biology, vol. 68, no. 4, pp. 450-456, 1995.

[118] A. J. Nappi, E. Vass, F. Frey, and Y. Carton, "Nitric oxide involvement in Drosophila immunity," Nitric Oxide, vol. 4, no. 4, pp. 423-430, 2000.

[119] E. H. Richards and M. P. Dani, "Biochemical isolation of an insect haemocyte anti-aggregation protein from the venom of the endoparasitic wasp, Pimpla hypochondriaca, and identification of its gene," Journal of Insect Physiology, vol. 54, no. 6, pp. 1041-1049, 2008.

[120] N. E. Beckage, "Modulation of immune responses to parasitoids by polydnaviruses," Parasitology, vol. 116, no. 1, pp. S57-S64, 1998.

[121] K. S. Shelby and B. A. Webb, "Polydnavirus-mediated suppression of insect immunity," Journal of Insect Physiology, vol. 45, no. 5, pp. 507-514, 1999.

[122] M. P. Dani and E. H. Richards, "Identification, cloning and expression of a second gene (vprl) from the venom of the endoparasitic wasp, Pimpla hypochondriaca that displays 
immunosuppressive activity," Journal of Insect Physiology, vol. 56, no. 2, pp. 195-203, 2010.

[123] Q. Fang, L. Wang, J. Zhu et al., "Expression of immuneresponse genes in lepidopteran host is suppressed by venom from an endoparasitoid, Pteromalus puparum," BMC Genomics, vol. 11, no. 1, article 484, 2010.

[124] G. Zhang, O. Schmidt, and S. Asgari, "A calreticulin-like protein from endoparasitoid venom fluid is involved in host hemocyte inactivation," Developmental and Comparative Immunology, vol. 30, no. 9, pp. 756-764, 2006. 

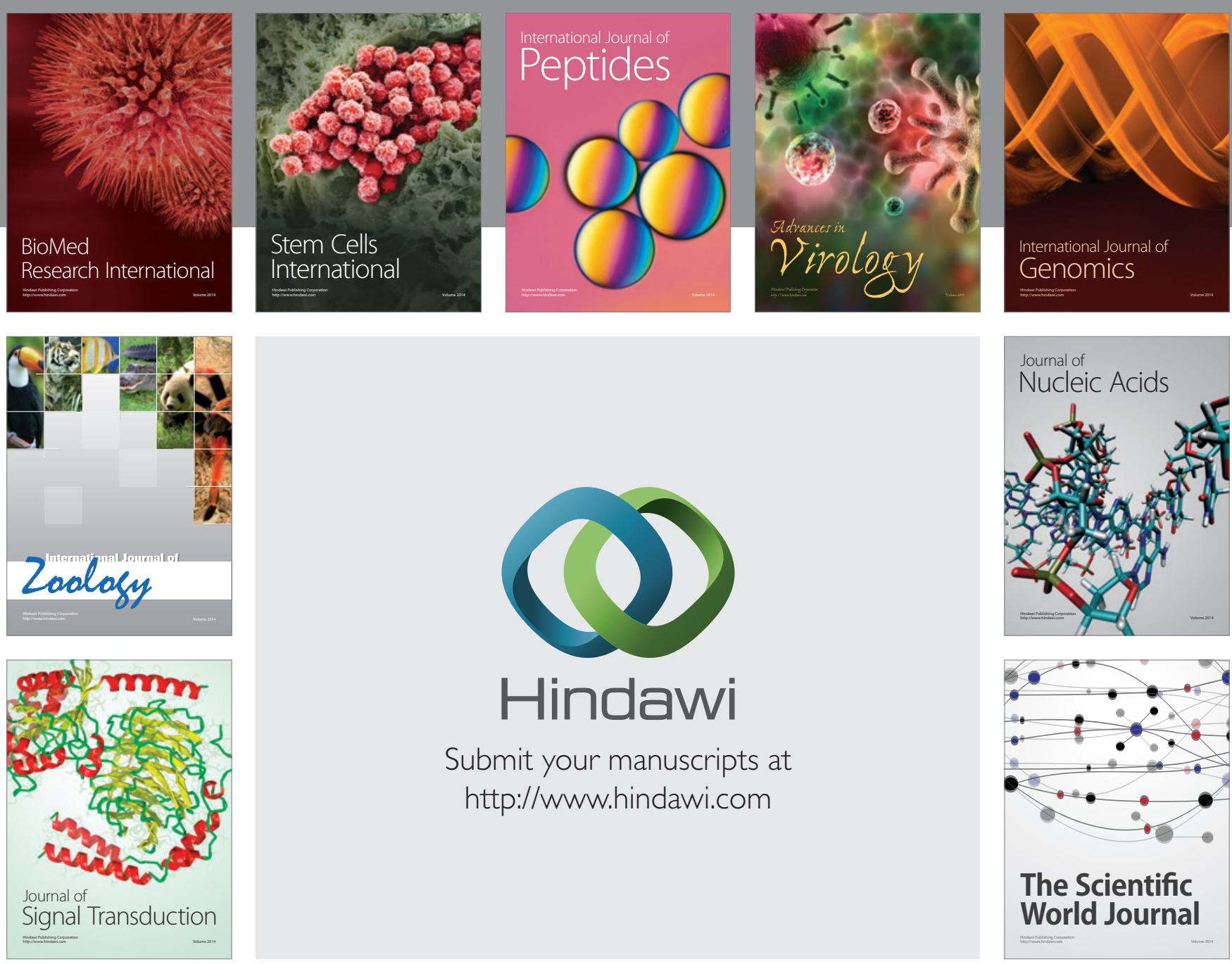

Submit your manuscripts at

http://www.hindawi.com
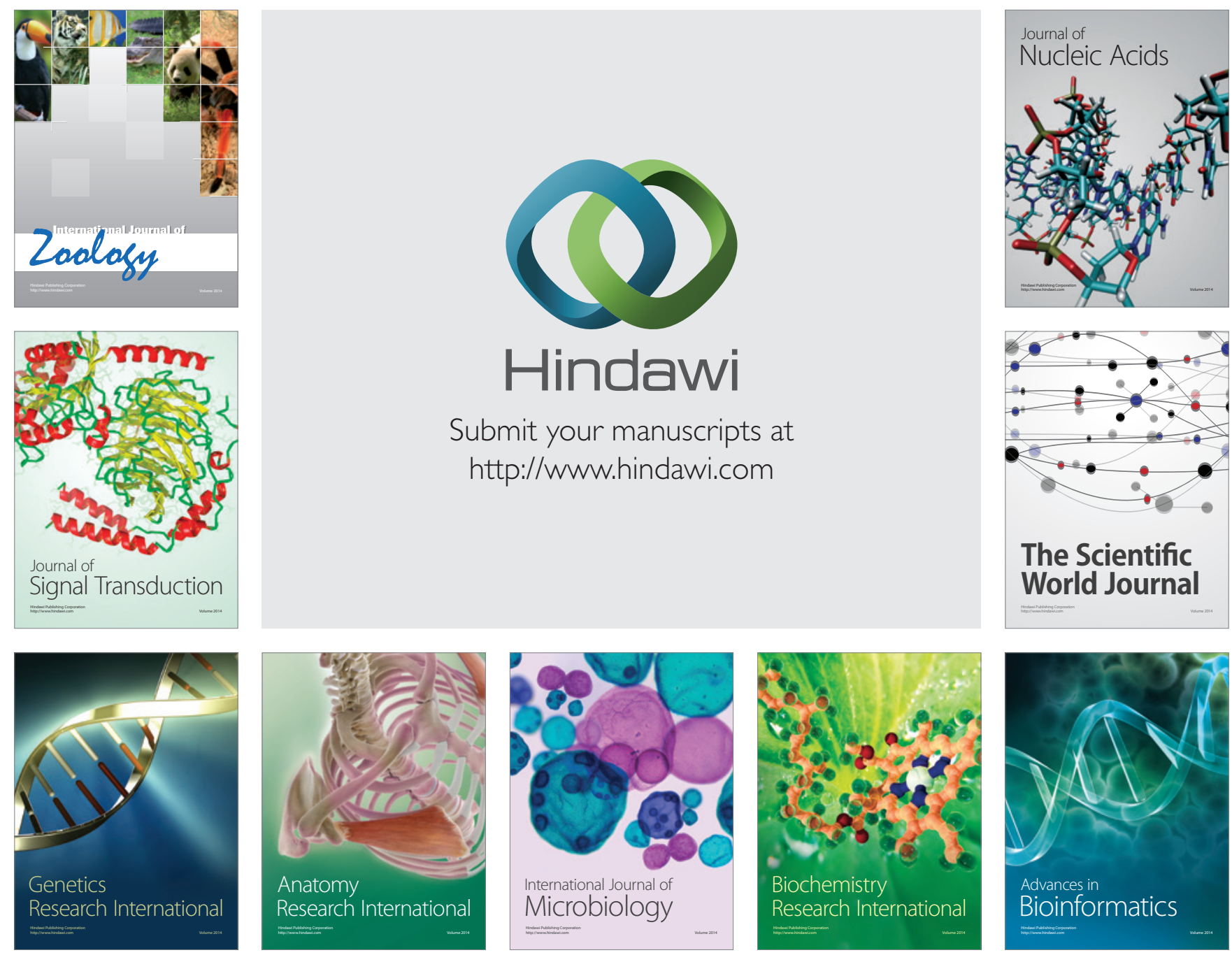

The Scientific World Journal
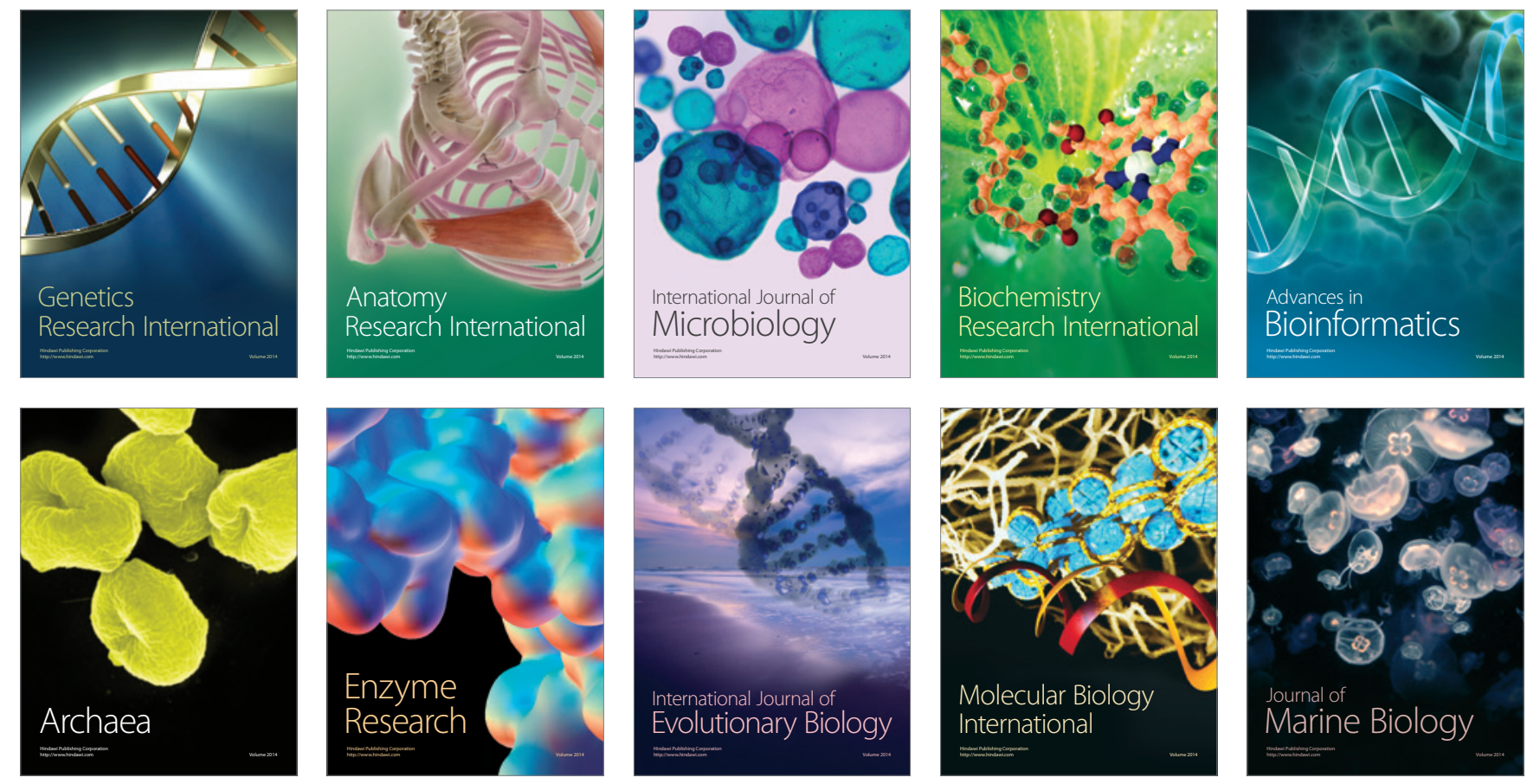